\title{
A Complete Set of Shadow Prices for Pakistan: Illustrations for 1975-76
}

\author{
Ehtisham Ahmad, DAVID COADY and Nicholas STERN*
}

\begin{abstract}
A consistent set of economy-wide shadow prices for Pakistan is presented, based on input-output flows for the mid-1970s. This provides broad parameters for policy at the sectoral level, with indications as to which sectors should be encouraged under alternative assumptions concerning the behaviour of factor markets. Further, these parameters are useful as inputs for project evaluation. A number of agricultural and manufacturing sectors are identified as being socially profitable. Finally, the shadow prices will be taken as parameters in a tax reform exercise.
\end{abstract}

\section{INTRODUCTION}

A consistent set of shadow prices provides many advantages in designing economic policy. In a previous paper (Ahmad and Stern 1986) we have shown how shadow prices could be used in an analysis of tax reform to evaluate the changes in net demands arising from tax changes. They can also be used, for example, to examine possible reorientations of trade and industrial policy in that they help to identify sectors which should be encouraged or discouraged. And, of course, they provide an essential input into project appraisal. They are, therefore, a most important tool for planning.

The main purpose of this paper is to provide a consistent set of economy-wide shadow prices for Pakistan. Since shadow prices embody the full effects of extra supply of a good, their calculation requires a model of the economy. Data limitations usually dictate that such a model be rather simple and essentially based on input-output information. The shadow prices presented in this paper are the first

*Ehtisham Ahmad is Principal Research Fellow and Deputy Director of Development Economics Research Centre, University of Warwick, and David Coady is presen tly associated with the London School of Economics while Nicholas Stern is Professor of Economics at the London School of Economics. This paper forms part of a project on the Tax System of Pakistan and Mexico, directed by Ehtisham Ahmad, Jesus Seade and Nicholas Stern, and supported by funds from the UKESRC and the World Bank under RPO 673-13. The opinions expressed here are not necessarily those of the ESRC or the World Bank. It forms a continuation of Ahmad and Stern (1986) and the authors are, as before, extremely grateful to Jean Dreze, Khalil Hamdani, Nizar Jetha, Jeffery Round, Jesus Seade, Asghar Qadir and Arshad Zaman for advice and helpful comments. 
to be based on such a data set - it was not available to earlier researchers such as Khan (1974), or Squire, Little and Durdag (1979). The information base also largely dictates the level of aggregation we can use, i.e. that of the input-output table. Hence, the shadow prices will be useful at the sectoral level in the analysis of policy and for tax reforms designed to shift from one broad class of goods to another. They will also be of value for broad classes of inputs in the analysis of particular investment projects. Our immediate motivation in calculating shadow prices was for the analysis of tax reform and their use in this context will be demonstrated in a subsequent paper. We shall comment briefly below on the implications of the shadow prices for the social value of expanding output in different sectors, i.e. which sectors should be encouraged and which discouraged. The method used in the estimation of shadow prices is described in Section 2. The estimates are based on the P.I.D.E. Input-Output Table of Pakistan's Economy: 1975-76. The data and calculation of shadow prices are described in Section 3. Section 4 concludes with reference to policy and further research.

\section{PRINCIPLES FOR THE COMPUTATION OF SHADOW PRICES}

The shadow price of a good is defined as the increase in social welfare which would arise if an extra unit of public supplies were to be made available. This definition requires us to calculate the full consequences of an extra unit, taking into account all the interactions of the economy, and then to evaluate the changes using some definition of social welfare. This is the definition that underlies the standard cost-benefit manuals (see e.g. Little and Mirrlees 1974 or Dasgupta, Marglin and Sen 1972) and it can easily be shown that this is essentially required for a cost-benefit test to correctly identify a social improvement - see Drèze and Stern (1987). Modelling the consequences of a small change in public supplies is, in principle, a formidable task and most methods of calculating shadow prices involve shortcuts in order to simplify. One of the best known procedures is that of Little and Mirrlees (1974) and this is the one followed here. We shall describe the method briefly below, indicating some of the most important assumptions involved in its justification.

Once shadow prices have been calculated they can be put to use in a much more disaggregated way than would be possible when using a fully articulated model of the economy. And they can also be adop ted to incorporate different views about, for example, the functioning of labour markets more easily than would be possible in a completely specified general equilibrium model. Hence, whilst one loses something in the description of the economy there is much to be gained in terms of disaggregation and flexibility.

\section{The Little-Mirrlees Model}

This method is based on a set of guiding principles which stand in place of a fully articulated model. Firstly, shadow (or accounting) prices for traded goods should be based on world or border prices, "border prices can be used as account ing prices for all traded goods, because they represent the opportunity costs or benefits of using or producing a traded good" (Little and Mirrlees, 1974, p. 68). The terms shadow and accounting prices will be used interchangeably in this paper. Secondly, "when considering the use of a non-traded good whose output will be consequentially expanded, then the accounting price is equal to the marginal social costs of production" (p. 70). In practice, when computing a system of accounting prices, this marginal social cost rule is generally used for all non-traded goods, and that is the method adopted here. The assumptions involved in using the rule across the board in this way are rather stringent and involve strong assumptions concerning the optimality of government policy (they are discussed formally in Drèze and Stern 1987). ${ }^{1}$ For more disaggregated sectoral work one can be more refined, asking in particular how much of an extra input used comes from extra production and how much from extra consumption. Some sensitivity analysis to the marginal social cost assumptions is provided by calculating shadow prices under various alternative assumptions concerning which goods are traded and which are not. Thirdly, the method takes explicit account of the way in which a project affects the distribution of income between public and private sectors and across individuals: "Thus government consumption, government saving, private consumption and private savings may all be considered to have different social values" (p. 71) and "we put considerable weight on the use of shadow wages as a means of allowing for the effects of a project on equality" (p. 72) and "The profits from a project are, of course, weighted according to whom they accrue" (p. 72). The quotes are all from Little and Mirrlees $\S 5.2$. The estimates of shadow prices thus incorporate judgements on income distribution most notably through the shadow wage. Further distributional considerations are introduced when the shadow prices are used in a reform analysis (see Ahmad and Stern 1986).

The method requires the classification of goods as being importable, export able, or non-traded at the margin. If it is assumed that extra supplies of a good are met through imports, then the sector is treated as "importable", and similarly for the other possibilities. Notice that the classification therefore depends in part on government policy - if there is a quota on a good which can be imported but the quota will not be changed, then we must treat the good as non-traded. One also has to consider how world markets and domestic production and consumption activities are likely to change over the future. Hence, one should never be completely confident about the appropriateness of one particular set of classifications and, accord ingly, we shall investigate a number of them in this paper.

${ }^{1}$ One hopes, however, that in the terms of broad sectoral accounting prices calculated here, they are not overly misleading and they do have the advantage of not requiring detaile demand information. 
The numeraire, or the unit of account for cost-benefit calculations for the Little-Mirrlees method is uncommitted foreign exchange in the hands of the government. Hence all domestic values are converted to a foreign exchange equivalent and incomes committed to particular uses (e.g. the consumptions of certain groups) are evaluated relative to uncommitted government income. We are now ready to describe the evaluation of traded and non-traded goods respectively. The calculation of shadow prices for goods which are traded at prices which may be treated as fixed on the world market is, in principle, straightforward. If the good is imported then its shadow price is the c.i.f. price, plus transport and distribution costs at shadow prices. Note, that taxes are excluded. If a good is exported, the shadow price is the f.o.b. price less transport and distribution costs at shadow prices. Where prices are not fixed one uses marginal revenues or marginal costs.

For practical estimation of economy-wide shadow prices, inter-industry transaction matrices or input-output tables are required. The most commonly used conventions for evaluating input-output tables are at (i) producer, or (ii) purchaser prices. Where purchaser prices are used, as for the Pakistan input-output table, inputs into industry $j$ include trade and transport margins. The cost of getting the output of industry $j$ to the point of purchase is included as a cost for the $i$ th industry. Thus using purchaser prices, the value of importable inputs includes both the import price and the margins incurred in getting the good to the using industry. The shadow price of an exportable reduces to its f.o.b. value and we can regard the shadow prices of exportables as exogenous. The shadow price of an importable, however, will depend on the shadow values of the trade and transport margins which are endogenously determined.

The shadow price for non-tradeables proposed by Little and Mirrlees is the marginal cost of an extra unit, valuing the inputs at shadow prices. The calculation of the marginal cost of non-traded goods at shadow prices therefore requires us to know the input requirements and the shadow prices of these inputs. The inputs will be traded goods, non-traded goods and factors. Thus to calculate the shadow price of one non-traded good we must know the shadow prices of the other non-traded goods. One also needs to know the shadow prices of factors; we return to these below.

The calculation of the shadow prices of non-traded goods then proceeds by decomposing the cost of a good into its constituent elements of taxes, payments for traded goods, and payments for each factor involved. The appropriate shadow prices are then applied to each element (zero in the case of taxes). This is possible using an input-output table provided (i) we can classify goods as traded or non-traded; (ii) we are prepared to make the assumption that the coefficient matrix, A, represents marginal requirements (at the relevant level of production); and (iii) we are able to decompose value added into constituent payments to factors. This calculation will obviously present certain difficulties in practice. The classification of goods into traded and non-traded is both important and problematic. For example, under any commodity grouping there will usually be an element of traded and non-traded goods, and varying degrees of violence to reality are involved in classifying a given sector as traded or non-traded. And even though a good may be tradeable, there may be an immovable quota which implies that the marginal unit must come from domestic production. We therefore consider more than one classification in traded and non-traded types of goods. These questions are discussed further in the next section in which we present the empirical work.

We can now express the rules we have described in terms of a set of equations for the endogenous shadow prices. We shall, for the moment, continue to regard the shadow prices of factors as exogenous so the endogenous shadow prices are for nontraded and importable goods. It is convenient to express all the shadow prices as proportions of market prices (here purchaser prices). The ratio of a shadow price to the market price is often called the accounting ratio. All the shadow prices in the formulae below are accounting ratios: essentially we choose units of commodities such that purchaser prices are unity.

We write $\bar{p}^{1}$ for the row vector $\left[p_{1}^{N}, \ldots, p_{n}^{N}, p_{1}^{a}, \ldots, p_{L}^{a}\right]$ of shadow prices for non-tradeables and importables, $A^{N M}$ for the matrix of coefficients which describe non-tradeable and importable inputs per unit of non-tradeable activities and trade and transport inputs into importables, $\bar{p}^{2}$ for the row vector of shadow prices of exportables and factors, and $A^{X N}$ for the matrix of coefficients of exportable inputs and factors into non-traded activities - see Table 1. We then have

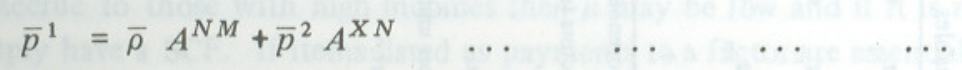

We can therefore solve for the endogenous shadow prices

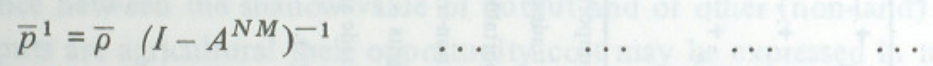

where

$$
\bar{\rho}=\bar{p}^{2} A^{X N}
$$$$
\cdots
$$$$
\ldots
$$$$
\ldots
$$$$
\ldots
$$

Factors constitute the final element in the computations of shadow prices. We have to calculate the opportunity cost, defined in terms of social welfare, of the employment of and payment to each type of factor. If the employment of an extra unit of a factor does not involve a payment to it over and above its earnings elsewhere, then the opportunity cost is the foregone output elsewhere. If those earnings represent its marginal product at market prices then the shadow value of the factor 
may be calculated by multiplying the market price of the factor by the ratio of shadow price to market price for the type of goods the factor might have produced. This ratio is often called a 'standard conversion factor' (SCF). Given that the numeraire is foreign exchange this SCF is the reciprocal of the 'shadow exchange rate' used in other methods of cost-benefit analysis. It should be emphasised, however, that there is no single SCF. The SCF we choose should depend on the bundle of goods that the factor would have produced elsewhere. This would differ, for example, as between rural and urban workers (see Drèze and Stern 1987, for further discussion).

Where the employment of an extra unit of a factor gives rise to earnings above those which would have been earned elsewhere, then the payment to factors overstates the cost since we have to take account of the benefits arising from the extra consumption. If $c$ is the payment to the factor and $m$ its earnings elsewhere (assumed equal to the marginal product) both at market prices, then the shadow price is SCF times

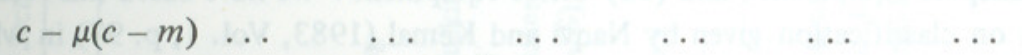

where $\mu$ is the value of extra income to the factor in terms of government revenue. Expression is the Little-Mirrlees shadow wage. If $\mu=0$ or $c=m$ then Expression (4) becomes $c$ and we simply multiply earnings by the SCF.

Examples of the use of the SCF and Expression (4) are as follows. Where labour is hired from a competitive labour market we would use a SCF (because $c=m$ ). A factor payment which is pure monopoly rent involves $m$ equal to zero and if these accrue to those with high incomes then $\mu$ may be low and if it is zero we again simply have a SCF. If items listed as payments to a factor are essentially payments for capital goods then we need a SCF for capital goods. The shadow price of land would involve a SCF for agricultural products since the shadow rent would be the difference between the shadow value of output and of other (non-land) inputs. If those inputs are agricultural their opportunity cost may be expressed in terms of agricultural goods.

\section{DATA AND THE CALCULATION OF SHADOW PRICES}

The results in this section are based on an 87-sector input-output table derived from the PIDE 118-sector matrix for the year 1975-76. We have used the smaller number of sectors since we wish to match the input-output data to tax revenue information for the calculation of shadow prices and effective taxes (see Ahmad and Stern 1986) and in the analysis of tax reform. The 87 factors must be classified, as we saw in the preceding section, into traded and non-traded activities. This classification is based on an assumed response of supply to demand changes. We consider 
only marginal changes. If a change in demand leads to a change in imports (exports) then the good is treated as imported (exported) on the margin. If the change leads to an adjustment in home production then the good is treated as non-traded.

One can make different sets of plausible assumptions concerning these adjustments and they are, in part, dependent on government policy. Accordingly, we work with three rather different classifications. In Case A we have 52 traded goods and 35 non-traded, and this has the maximum number of traded sectors (see Table 2). In case B, there are 39 non-traded goods, with (1) 'wheat', (8) 'other crops', (9) 'livestock' and (12) 'mining and quarrying' no longer being treated as traded. In going from case $\mathrm{A}$ to case $\mathrm{C}$ we have reclassified fourteen sectors as nontraded to allow for binding quotas giving 49 non-traded sections in all. These categories include: (16) 'sugar refining', (18) 'tea blending', (29) 'silk and synthetic textiles', (30) 'woollen textiles', (35) 'wood, cork and furniture', (36) 'paper and products', (40) 'rubber products', (41) 'pharmaceuticals', (43), 'perfumes and cosmetics', (46) 'chemicals', (48) 'petroleum products', (59) 'transport (large-scale)', (61) 'transport equipment', and (62) 'office equipment'. We have based this reclassification on classification given by Naqvi and $\operatorname{Kemal}(1983$, Vol. 1, p. 97) in which implicit nominal protection rates, which use market prices, are compared with explicit nominal protection rates, which use published tariff rates. When the former exceed the latter, then quotas are taken as binding. Whilst the PIDE study was conducted for the year 1981, we have made the supposition that there were at least as many quotas in the earlier period 1975-76.

In practice, within an input-output category, there may be several commodities which are non-traded, or which have quotas associated with them, and others which are clearly traded. At the level of disaggregation available to us, many sectors are both traded and non-traded, and we have tried to use informed judgement on the basis of data relating to imports and exports. It would be useful to use the broad indicators resulting from the study as an input into more detailed analyses, in which commodities may be more adequately identified as tradeable or non-tradeable.

Once we have assembled information on inputs, outputs and taxes and classified sectors into tradeables and non-tradeables, one can apply the method described in Section 2. We consider shadow prices for exportables, importables, factors and non-traded goods in that order.

We express a shadow price in terms of its 'accounting ratios' (or AR) which is the shadow price divided by the market price. The values used in the input-output table are at purchaser prices. For exported goods, these are taken as equivalent to f.o.b. values and the accounting ratios are 1 for goods which do not have export taxes. The commodities which had major export taxes in 1975-76 are rice, raw cotton, leather and cotton waste. The Appendix Table 1 (i) gives details of export taxes, f.o.b. export values from FBS (1983) and the accounting ratios. The ARs are $\because$

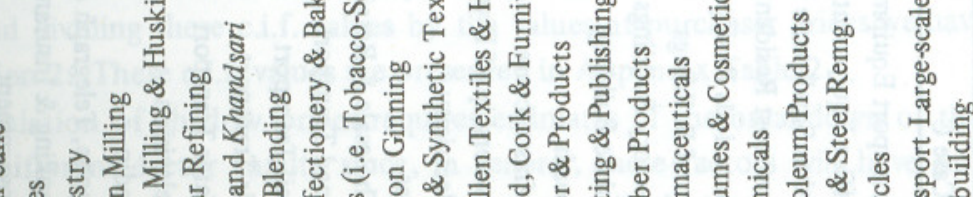

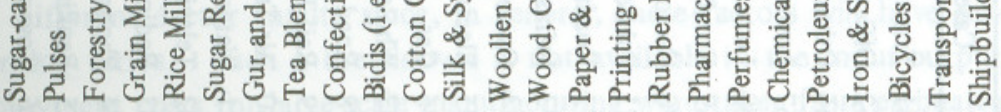
पธ㇒士

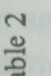

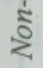

ธすั์

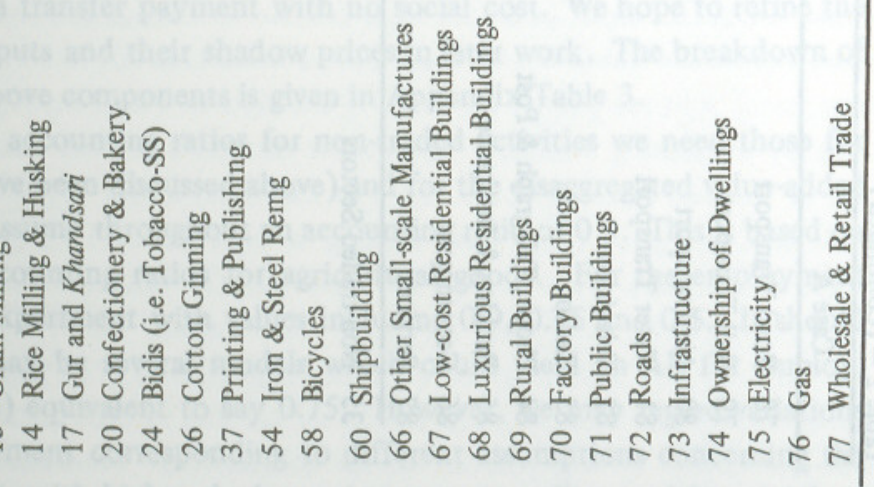


derived as a proportion of f.o.b. to purchaser price values, where the latter are f.o.b. values less the export tax.

For imports, the final P.I.D.E. Input-Output Table (1985) presents gross absorportions at purchaser prices. Taking off taxes and trade and transport margins (derived from the relevant rows in the input-output table) we may work out the c.if. values and dividing these c.i.f. values by the values at purchaser prices we have $p_{1}^{c i f}$-see Section 2. These c.i.f. values are presented in Appendix Table 2.

The calculation of shadow prices requires estimates of the breakdown of the payments to different factor inputs since, in general, these factors will have different accounting ratios. Such a breakdown is not available in the input-output matrix. Employment costs for large-scale manufacturing were taken from estimates calculated from the Census of Manufacturing Industry (CMI) for the 118-sector classification. However, since the value-added figures for the input-output study were lower than those for large-scale manufacturing from the CMI, the employment costs have been adjusted downwards by a factor of 0.658 to match the input-output estimates. We have assumed other employment costs as follows: 0.5 of value added in agriculture and small-scale industries, and 0.6 of value added in construction and services. For agriculture, we have taken land opportunity costs at market prices as 0.3 of value added. Capital coefficients have been described in a previous paper [see Ahmad and Stern (1986) where we used a rental charge based on a rate of interest of 10 percent]. The residual of value added, after these elements have been deducted, is "pure profit". It is sometimes positive and sometimes negative. Given that it is an item derived as a residual after many assumptions, it is not likely to be accurate. We have ignored it in the calculation of shadow prices which essentially involves treating it as a transfer payment with no social cost. We hope to refine the treatment of factor inputs and their shadow prices in later work. The breakdown of value added into the above components is given in Appendix Table 3.

To calculate the accounting ratios for non-traded activities we need those for traded goods (these have been discussed above) and for the disaggregated value-added terms. For land, we assume throughout an accounting ratio of 0.9 . This is based on a rough average of accounting ratios for agricultural goods. For the employment accounting ratio, we experiment with values including $0.9,0.75$ and 0.5 . It should be noted that there may be several models which could yield an AR for employment (or shadow wage) equivalent to say 0.75 . However, we may regard variations in the AR for employment corresponding to different assumptions concerning the Pakistan labour market, with higher shadow prices corresponding to tighter markets or greater social costs of employment. These different assumptions could include, for instance, models which incorporate the migration of Pakistani workers to the Middle East and others which do not. Lower ARs would correspond to cases where one assumes a relative abundance of labour. The numbers used also cover a range 
that has been generated by detailed studies, see for example Squire, Little and Durdag (1979) and Khan (1974). The reason that 0.9 is the maximum AR we have used is based on Section 2 where we state that the shadow price is the SCF times Expression (4). Given the high tariffs in Pakistan, 0.9 would be a high estimate for the SCF corresponding to labour, and this in turn would be multiplied by a factor less than one corresponding to Expression (4).

In a similar manner, an AR for assets may be generated by different combinations of the accounting rate of interest $(r)$, the capital matrix, and the shadow price of capital goods. We have taken values of $0.75,0.5$ and 0.25 to provide a wide range of alternatives. For example, if 10 percent is thought to be reasonable for $r$ and our estimate of the capital coefficient matrix (see Ahmad and Stern 1986) is satisfactory, then the appropriate AR is that corresponding to capital goods (so that the shadow cost of equipment is $r$ times its value at market prices times the AR). In this case 0.75 might be plausible. Alternatively, if 10 percent is thought to be too high for a real accounting rate of interest (and historically this might be so) then a lower AR might be more appropriate. Given the uncertainty concerning the estimates (particularly of $r$ and the capital matrix) we have chosen the broad range.

The accounting ratios for non-traded goods corresponding to each combination of the ARs for labour and assets are presented for Case $\mathrm{C}$ in Table 3. Those for cases A and B, which have fewer non-traded sectors, are presented in Appendix Table 4. Recall that we value the residual profit/loss at zero thus treating it as a transfer payment with no social cost. Therefore, ceteris paribus, one would expect the ARs for non-traded activities which exhibit high positive residuals to have relatively low ARs and those which have high negative residuals to have relatively high ARs (because the social input costs are high relative to the value of output). As one can see from Appendix Table 4 and Table 3, this holds true for most non-traded ARs. However, some ARs are greatly affected by the ARs of major inputs. These effects can be seen by examining Table 3 . The results discussed are for Case $\mathrm{C}$ with employment $\mathrm{AR}$ of 0.9 and asset AR of 0.75 . For example, sector (1) 'wheat' has a high AR of 1.30 and this gives (13) 'grain milling' a high AR of 1.32 (grain milling also has a negative residual). Also sectors (2) 'rice' and (3) 'cotton' have high ARs of 1.11 and 1.51 respectively, and these give (14) 'rice milling' and (26) 'cotton ginning' high ARs of 1.05 and 1.36 respectively. The high ARs of (73) 'infrastructure', (75) 'electricity', (76) 'gas' and (79) 'rail transport' are due to high negative residuals, which in turn are caused by high capital service coefficients. Thus charging appropriately for capital inputs implies a high social cost of production relative to the market value of output. One will also notice that activities with high labour coefficients are most sensitive to the wage conversion factor chosen - for example (79) 'wholesale trade'. Those which have high capital coefficients are most sensitive to the asset conversion factor chosen e.g. (73) 'infrastructure', (74) 'ownership of dwellings', (95) 'electricity' and (76) 'gas'.
Table 3 (i)

Case C: ARs for Non-traded Goods Corresponding to an AR for Assets of 0.75

\begin{tabular}{|c|c|c|c|c|c|}
\hline & & \multirow{2}{*}{ Commodity } & \multicolumn{3}{|c|}{ Labour AR } \\
\hline & & & 0.9 & 0.75 & 0.5 \\
\hline 1 & 04 & Sugar-cane & 0.7524 & 0.6821 & 0.5648 \\
\hline 2 & 07 & Pulses & 0.8860 & 0.8495 & 0.7886 \\
\hline 3 & 11 & Forestry & 0.7238 & 0.6476 & 0.5207 \\
\hline 4 & 13 & Grain Milling & 1.3165 & 1.2992 & 1.2705 \\
\hline 5 & 14 & Rice Milling \& Husking & 1.0494 & 1.0287 & 0.9943 \\
\hline 6 & 16 & Sugar Refining & 0.5332 & 0.4865 & 0.4085 \\
\hline 7 & 17 & Gur and Khandsari & 0.7366 & 0.6538 & 0.5325 \\
\hline 8 & 18 & Tea Blending & 0.5438 & 0.4972 & 0.4195 \\
\hline 9 & 20 & Confectionery \& Bakery & 0.7293 & 0.6871 & 0.6166 \\
\hline 10 & 24 & Bidis (i.e. Tobacco-SS) & 0.6013 & 0.5432 & 0.4463 \\
\hline 11 & 26 & Cotton Ginning & 1.3570 & 1.3473 & 1.3312 \\
\hline 12 & 29 & Silk \& Synthetic Textiles & 0.7748 & 0.7251 & 0.6423 \\
\hline 13 & 30 & Woollen Textiles \& Hosiery & 0.8307 & 0.7892 & 0.7199 \\
\hline 14 & 35 & Wood, Cork \& Furniture & 0.6681 & 0.6091 & 0.5106 \\
\hline 15 & 36 & Paper \& Products & 0.6163 & 0.5613 & 0.4696 \\
\hline 16 & 37 & Printing \& Publishing & 0.6225 & 0.5652 & 0.4696 \\
\hline 17 & 40 & Rubber Products & 0.7472 & 0.7035 & 0.6308 \\
\hline 18 & 41 & Pharmaceutical & 0.6248 & 0.5806 & 0.5070 \\
\hline 19 & 43 & Perfumes \& Cosmetics & 0.6289 & 0.5765 & 0.4891 \\
\hline 20 & 46 & Chemicals & 0.6426 & 0.5984 & 0.5248 \\
\hline 21 & 48 & Petroleum Products & 0.8731 & 0.8496 & 0.8106 \\
\hline 22 & 54 & Iron \& Steel Remg & 0.5900 & 0.5170 & 0.3954 \\
\hline 23 & 58 & Bicycles & 0.7721 & 0.7447 & 0.6990 \\
\hline 24 & 59 & Transport Large-scale & 0.7440 & 0.7209 & 0.6824 \\
\hline 25 & 60 & Shipbuilding & 0.8568 & 0.8164 & 0.7489 \\
\hline 26 & 61 & Transport Equipment Small-scale & 0.6863 & 0.6284 & 0.5319 \\
\hline 27 & 62 & Office Equipment & 0.6852 & 0.6441 & 0.5755 \\
\hline 28 & 66 & Other Small-scale Manufacturing & 0.6006 & 0.5563 & 0.4824 \\
\hline 29 & 67 & Low-cost Residential Buildings & 0.7585 & 0.7110 & 0.6319 \\
\hline 30 & 68 & Luxurious Residential Buildings & 0.7360 & 0.6866 & 0.6043 \\
\hline 31 & 69 & Rural Buildings & 0.7174 & 0.6582 & 0.5594 \\
\hline 32 & 70 & Factory Buildings & 0.7348 & 0.6880 & 0.6099 \\
\hline 33 & 71 & Public Buildings & 0.7217 & 0.6691 & 0.5814 \\
\hline 34 & 72 & Roads & 0.7320 & 0.6789 & 0.5904 \\
\hline 35 & 73 & Infrastructure & 1.1042 & 1.0540 & 0.9702 \\
\hline 36. & 74 & Ownership of Dwellings & 0.7329 & 0.6475 & 0.5053 \\
\hline 37 & 75 & Electricity & 1.7528 & 1.6752 & 1.5459 \\
\hline 38 & 76 & Gas & 1.7067 & 1.6305 & 1.5034 \\
\hline 39 & 77 & Wholesale \& Retail Trade & 0.6329 & 0.5438 & 0.3954 \\
\hline 40 & 78 & Road Transport & 0.7485 & 0.6956 & 0.6074 \\
\hline 41 & 79 & Rail Transport & 0.9625 & 0.9043 & 0.8074 \\
\hline 42 & 80 & Air Transport & 0.7106 & 0.6476 & 0.5426 \\
\hline 43 & 81 & Water Transport & 0.6351 & 0.5524 & 0.4146 \\
\hline 44 & 82 & Television & 0.7287 & 0.6682 & 0.5672 \\
\hline 45 & 83 & Radio & 0.6773 & 0.5945 & 0.4565 \\
\hline 46 & 84 & Phone, Telegraph \& Post & 0.8189 & 0.7355 & 0.5965 \\
\hline 47 & 85 & Banking \& Insurance & 0.6504 & 0.5681 & 0.4310 \\
\hline 48 & 86 & Government & 0.8369 & 0.7566 & 0.6227 \\
\hline 49 & 87 & Services & 0.6324 & 0.5435 & 0.3953 \\
\hline
\end{tabular}


Table 3 (ii)

Case C: ARs for Non-traded Goods Corresponding to an AR for Assets of 0.5

Table 3 (iii)

\begin{tabular}{|c|c|c|c|c|c|}
\hline & & \multirow{2}{*}{ Commodity } & \multicolumn{3}{|c|}{ Labour AR } \\
\hline & & & 0.9 & 0.75 & 0.5 \\
\hline 1 & 04 & Sugar-cane & 0.7368 & 0.6665 & 0.5492 \\
\hline 2 & 07 & Pulses & 0.8680 & 0.8315 & 0.7706 \\
\hline 3 & 11 & Forestry & 0.7123 & 0.6361 & 0.5091 \\
\hline 4 & 13 & Grain Milling & 1.2827 & 1.2654 & 1.2367 \\
\hline 5 & 14 & Rice Milling \& Husking & 1.0104 & 0.9897 & 0.9552 \\
\hline 6 & 16 & Sugar Refining & 0.4984 & 0.4516 & 0.3737 \\
\hline 7 & 17 & Gur and Khandsari & 0.7058 & 0.6330 & 0.5117 \\
\hline 8 & 18 & Tea Blending & 0.4654 & 0.4188 & 0.3411 \\
\hline 9 & 20 & Confectionery \& Bekery & 0.6786 & 0.6363 & 0.5659 \\
\hline 10 & 24 & Bidis (i.e. Tobacco-SS) & 0.5854 & 0.5273 & 0.4304 \\
\hline 11 & 26 & Cotton Ginning & 1.3293 & 1.3196 & 1.3035 \\
\hline 12 & 29 & Silk \& Synthetic Textiles & 0.7110 & 0.6614 & 0.5786 \\
\hline 13 & 30 & Woollen Textiles \& Hosiery & 0.7885 & 0.7470 & 0.6778 \\
\hline 14 & 35 & Wood, Cork \& Furniture & 0.6318 & 0.5727 & 0.4743 \\
\hline 15 & 36 & Paper \& Products & 0.5471 & 0.4921 & 0.4004 \\
\hline 16 & 37 & Printing \& Publishing & 0.5619 & 0.5045 & 0.4090 \\
\hline 17 & 40 & Rubber Products & 0.7027 & 0.6591 & 0.5864 \\
\hline 18 & 41 & Pharmaceutical & 0.5584 & 0.5142 & 0.4407 \\
\hline 19 & 43 & Perfumes \& Cosmetics & 0.5770 & 0.5246 & 0.4372 \\
\hline 20 & 46 & Chemicals & 0.5753 & 0.5312 & 0.4576 \\
\hline 21 & 48 & Petroleum Products & 0.8395 & 0.8161 & 0.7771 \\
\hline 22 & 54 & Iron \& Steel Remg. & 0.5643 & 0.4913 & 0.3697 \\
\hline 23 & 58 & Bicycles & 0.7327 & 0.7053 & 0.6596 \\
\hline 24 & 59 & Transport/Large-scale & 0.7072 & 0.6841 & 0.6456 \\
\hline 25 & 60 & Shipbuilding & 0.8170 & 0.7766 & 0.7091 \\
\hline 26 & 61 & Transport Equipment Small-scale & 0.6466 & 0.5887 & 0.4922 \\
\hline 27 & 62 & Office Equipment & 0.6234 & 0.5822 & 0.5137 \\
\hline 28 & 66 & Other Small-scale Manufacturing & 0.5847 & 0.5404 & 0.4665 \\
\hline 29 & 67 & Low-cost Residential Buildings & 0.7539 & 0.7065 & 0.6274 \\
\hline 30 & 68 & Luxurious Residential Buildings & 0.7287 & 0.6793 & 0.5970 \\
\hline 31 & 69 & Rural Buildings & 0.7110 & 0.6518 & 0.5530 \\
\hline 32 & 70 & Factory Buildings & 0.7296 & 0.6827 & 0.6047 \\
\hline 33 & 71 & Public Buildings & 0.7139 & 0.6613 & 0.5736 \\
\hline 34 & 72 & Roads & 0.7288 & 0.6757 & 0.5872 \\
\hline 35 & 73 & Infrastructure & 0.9704 & 0.9202 & 0.8364 \\
\hline 36 & 74 & Ownership of Dwellings & 0.6748 & 0.5895 & 0.4472 \\
\hline 37 & 75 & Electricity & 1.3633 & 1.2857 & 1.1564 \\
\hline 38 & 76 & Gas & 1.3390 & 1.2628 & 1.1357 \\
\hline 39 & 77 & Wholesale \& Retail Trade & 0.6027 & 0.5137 & 0.3652 \\
\hline 40 & 78 & Road Transport & 0.7092 & 0.6563 & 0.5680 \\
\hline 41 & 79 & Rail Transport & 0.8557 & 0.7976 & 0.7007 \\
\hline 42 & 80 & Air Transport & 0.6757 & 0.6127 & 0.5076 \\
\hline 43 & 81 & Water Transport & 0.6130 & 0.5303 & 0.3925 \\
\hline 44 & 82 & Television & 0.6982 & 0.6376 & 0.5367 \\
\hline 45 & 83 & Radio & 0.6372 & 0.5544 & 0.4164 \\
\hline 46 & 84 & Phone, Telegraph \& Post & 0.7305 & 0.6471 & 0.5081 \\
\hline 47 & 85 & Banking \& Insurance & 0.6200 & 0.5377 & 0.4006 \\
\hline 48 & 86 & Government & 0.7472 & 0.6669 & 0.5330 \\
\hline 49 & 87 & Services & 0.6021 & 0.5133 & 0.3651 \\
\hline
\end{tabular}

Case C: ARs for Non-traded Goods Corresponding to an AR for Assets of 0.25

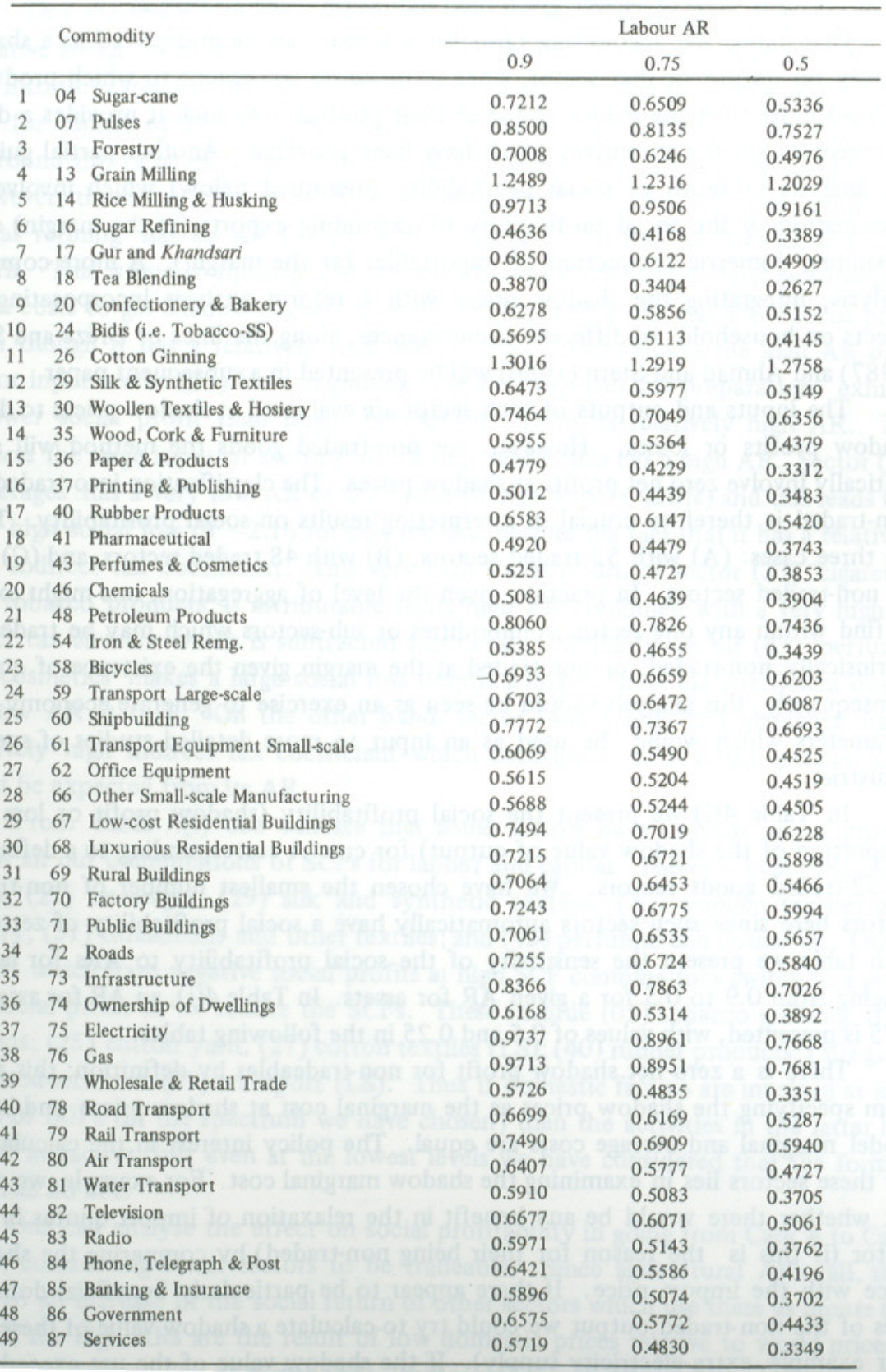


The ARs for importables are presented in Appendix Table 1(ii) and (iii). Note that they are insensitive both to the classification of A versus $C$ and to the ARs for labour. This is to be expected, given their definition - see Section 2.

One minus the accounting ratio for a sector can be interpreted as a shadow subsidy on output in that sector, since it measures the extent to which producers are paid more than the shadow price of their product. As such it provides a direct commentary on the incentives which have been provided. Another partial guide is the analysis in terms of social profitability (described below) which involves an examination of the social profitability of expanding exports (at the margin) or of expanding domestic production of importables (at the margin). A more complete analysis, integrating the shadow prices with a reform analysis incorporating the effects on households in different circumstances, along the lines of Drèze and Stern (1987) and Ahmad and Stern (1986) will be presented in a subsequent paper.

The inputs and outputs of each sector are evaluated at shadow prices to derive shadow profits or losses. However, for non-traded goods the method will automatically involve zero net profits at shadow prices. The classification into traded and non-traded is therefore crucial in interpreting results on social profitability. There are three cases: (A) with 52 traded sectors, (B) with 48 traded sectors, and (C) with 38 non-traded sectors. In practice, given the level of aggregation, one might expect to find within any one sector, commodities or sub-sectors which may be traded, or intrinsically non-traded, or non-traded at the margin given the existence of quotas. Consequently, this analysis should be seen as an exercise to generate economy-wide parameters which would be used as an input to more detailed studies of specific industries.

In Table 4(i) we present the social profitability (shadow profit or loss as a proportion of the shadow value of output) for case A corresponding to a definition of 52-traded goods sectors. We have chosen the smallest number of non-traded sectors here since such sectors automatically have a social profitability of zero. In each table we present the sensitivity of the social profitability to ARs for labour ranging from 0.9 to 0.5 for a given AR for assets. In Table 4(i), an AR for assets of 0.75 is presented, with values of 0.5 and 0.25 in the following tables.

There is a zero net shadow profit for non-tradeables by definition; this arises from specifying the shadow prices as the marginal cost at shadow prices, and in this model marginal and average costs are equal. The policy interest in the calculations for these sectors lies in examining the shadow marginal cost. For example, we could ask whether there would be any benefit in the relaxation of import quotas in that sector (if this is the reason for their being non-traded) by comparing the shadow price with the import price. If there appear to be particularly beneficial domestic uses of the non-traded output we could try to calculate a shadow value of these uses (for example, extra electricity supply). If the shadow value of the use exceeds the shadow marginal cost, then one might argue that the output should be expanded and directed towards the beneficial use.

One expects that activities whose outputs have relatively low ARs will exhibit negative social profitability. In general, sectors with an AR less than 0.75 tend to fall into this category. We focus on Case A with a conversion factor for labour of 0.9 and for capital of 0.75 and this implies that the average AR applied to input costs is around the value of 0.75 . Thus an AR for output of 0.75 is a rough dividing line. However, there are a few exceptions to this general rule. For instance, sector (16) 'sugar refining' has an AR less than the mean (at 0.64) and yet it exhibits a social profit. This is due to the large indirect tax element $(0.25)$ which must be subtracted from costs to get shadow prices. Also, sector (15) 'edible oils' has a low social profit even though it has a relatively high AR of 0.95. This reflects the high AR of its major input sector (26) 'cotton ginning'. Sector (19) 'fish and preparations' exhibits a lower social profit than might be expected from its relatively high AR. This reflects the large input of sector (10) 'fishing' which also has a high AR. Sector (22) 'beverages' has a very low AR of 0.17 (due to high import tariffs) and this leads to a very high social loss of -2.16 for this activity, despite the fact that it has a relatively high indirect tax coefficient. This very high social return of sector (23) 'cigarettes and tobacco products' is attributable to its high AR combined with a very high indirect tax element which is subtracted from costs. Similarly, sector (43) 'perfumes and cosmetics' makes a large social loss despite a high indirect tax coefficient due to its low AR at 0.18. On the other hand, sector (44) 'paints and varnishes' has a relatively high indirect tax coefficient which contributes to a return greater than might be expected from its AR.

From Table 4(i) one can see that some sectors have negative social profits across all our combinations of SCFs for labour and capital. These include (08) other crops; (22) beverages; (29) silk and synthetic textiles; (30) woollen textiles and hosiery; (31) threadballs and other textiles; and (43) perfumes and cosmetics. Other sectors which have negative social profits at high SCF combinations switch to a positive social profit as we reduce the SCFs. These include (05) tobacco growing; (06) oilseeds; (25) cotton yarn; (27) cotton textiles (LS); (40) rubber products; (50) glass and products; and (59) transport (LS). Thus if domestic factors are involved at low levels of SCFs (in the spectrum we have chosen) then the activities in the latter list appear attractive; but even at the lowest levels we have considered that the former activities do not.

One can analyse the effect on social profitability in going from Case A to Case B, i.e. considering fewer sectors to be tradeable. Since agricultural ARs fall, this leads to an increase in the social return of other sectors which use these as inputs (in Case A the high ARs are the result of low domestic prices relative to world prices). The social profitability of sector (38) 'leather and products' increases, reflecting the 
Table 4 (i)

Case A: Social Profitability with an Asset AR of 0.75

\begin{tabular}{|c|c|c|c|c|}
\hline & \multirow{2}{*}{ Commodity } & \multicolumn{3}{|c|}{ Labour ARs } \\
\hline & & 0.9 & 0.75 & 0.5 \\
\hline 01 & Wheat & 0.3973 & 0.4332 & 0.4939 \\
\hline 02 & Rice & 0.2657 & 0.3152 & 0.3977 \\
\hline 03 & Cotton & 0.4717 & 0.5124 & 0.5801 \\
\hline 04 & Sugar-cane & 0.0000 & 0.0000 & 0.0000 \\
\hline 05 & Tobacco Growing & -0.0181 & 0.0606 & 0.1965 \\
\hline 06 & Oilseeds & -0.1176 & -0.0510 & 0.0638 \\
\hline 07 & Pulses & 0.0000 & 0.0000 & 0.0000 \\
\hline 08 & Other Crops & -0.3336 & -0.2515 & -0.1082 \\
\hline 09 & Livestock & 0.2368 & 0.2869 & 0.3712 \\
\hline 10 & Fishing & 0.2657 & 0.3394 & 0.4623 \\
\hline 11 & Forestry & 0.0000 & 0.0000 & 0.0000 \\
\hline 12 & Mining \& Quarrying & 0.1968 & 0.2641 & 0.3790 \\
\hline 13 & Grain Milling & 0.0000 & 0.0000 & 0.0000 \\
\hline 14 & Rice Milling \& Husking & 0.0000 & 0.0000 & 0.0000 \\
\hline 15 & Edible Oils & 0.0666 & 0.0803 & 0.1036 \\
\hline 16 & Sugar Refining & 0.1708 & 0.2313 & 0.3362 \\
\hline 17 & Gur and Khandsari & 0.0000 & 0.0000 & 0.0000 \\
\hline 18 & Tea Blending & 0.1618 & 0.1773 & 0.2033 \\
\hline 19 & Fish \& Preparations & 0.1054 & 0.1264 & 0.1613 \\
\hline 20 & Confectionery \& Bakery & 0.0000 & 0.0000 & 0.0000 \\
\hline 21 & Other Food Industries & 0.2645 & 0.3103 & 0.3866 \\
\hline 22 & Beverages & -2.1608 & -2.2111 & -2.3274 \\
\hline 23 & Cigs. \& Tobacco Products Large-scale & 0.6453 & 0.6622 & 0.6903 \\
\hline 24 & Bidis (i.e. Tobacco-SS) & 0.0000 & 0.0000 & 0.0000 \\
\hline 25 & Cotton Yarn & -0.0525 & -0.0251 & 0.0206 \\
\hline 26 & Cotton Ginning & 0.0000 & 0.0000 & 0.0000 \\
\hline 27 & Cotton Textiles (Large-scale) & -0.0271 & 0.0086 & 0.0681 \\
\hline 28 & Cotton Textiles (Small-scale) & 0.1638 & 0.1928 & 0.2411 \\
\hline 29 & Silk \& Synthetic Textiles & -0.4236 & -0.3903 & -0.3308 \\
\hline 30 & Woollen Textiles \& Hosiery & -0.4459 & -0.4183 & -0.3686 \\
\hline 31 & Threadballs \& other Textiles & -0.2281 & -0.2003 & -0.1511 \\
\hline 32 & Carpets \& Rugs & 0.3532 & 0.3867 & 0.4426 \\
\hline 33 & Made-up Garments & 0.2594 & 0.2829 & 0.3221 \\
\hline 34 & Footwear (non-rubber) & 0.1547 & 0.1907 & 0.2506 \\
\hline 35 & Wood, Cork \& Furniture & 0.3007 & 0.3557 & 0.4474 \\
\hline 36 & Paper \& Products & 0.0647 & 0.1052 & 0.1772 \\
\hline 37 & Printing \& Publishing & 0.0000 & 0.0000 & 0.0000 \\
\hline 38 & Leather \& Products & 0.2827 & 0.2945 & 0.3143 \\
\hline 39 & Rubber Footwear & 0.2422 & 0.2886 & 0.3660 \\
\hline 40 & Rubber Products & -0.1118 & -0.0760 & -0.0121 \\
\hline 41 & Pharmaceutical & 0.2421 & 0.2621 & 0.2963 \\
\hline 42 & Fertilizer & 0.1646 & 0.1943 & 0.2458 \\
\hline 43 & Perfumes \& Cosmetics & -2.7978 & -2.7328 & -2.6100 \\
\hline
\end{tabular}

\begin{tabular}{|c|c|c|c|c|}
\hline & \multirow[t]{2}{*}{ Commodity } & \multicolumn{3}{|c|}{ Labour ARs } \\
\hline & & 0.9 & 0.75 & 0.5 \\
\hline 44 & Paints \& Varnishes & 0.1342 & 0.1479 & 0.1716 \\
\hline 45 & Soaps \& Detergents & 0.1637 & 0.1817 & 0.2128 \\
\hline 46 & Chemicals & 0.1864 & 0.2216 & 0.2823 \\
\hline 47 & Plastic Products & 0.2721 & 0.3175 & 0.3951 \\
\hline 48 & Petroleum Products & 0.0315 & 0.0449 & 0.0680 \\
\hline 49 & Cement & 0.1731 & 0.2169 & 0.2900 \\
\hline 50 & Glass \& Products & -1.3082 & -1.2110 & -1.0391 \\
\hline 51 & Non-Met. Mineral Products & 0.1220 & 0.1500 & 0.1977 \\
\hline 52 & Basic Metals & 0.0264 & 0.0571 & 0.1111 \\
\hline 53 & Metal Products & 0.1609 & 0.2205 & 0.3239 \\
\hline 54 & Iron \& Steel Remg & 0.0000 & 0.0000 & -0.0000 \\
\hline 55 & Agricultural Machinery & 0.1278 & 0.1442 & 0.1720 \\
\hline 56 & Other Non-electric Machinery & 0.2173 & 0.2476 & 0.2989 \\
\hline 57 & Electric Machnery & 0.0873 & 0.1101 & 0.1487 \\
\hline 58 & Bicycles & 0.0000 & 0.0000 & 0.0000 \\
\hline 59 & Transport Large-scale & -0.0893 & -0.0681 & -0.0320 \\
\hline 60 & Shipbuilding & 0.0000 & 0.0000 & 0.0000 \\
\hline 61 & Transport Equipment Small-scale & 0.1852 & 0.2191 & 0.2761 \\
\hline 62 & Office Equipment & 0.2185 & 0.2405 & 0.2779 \\
\hline 63 & Sports Goods & 0.2630 & 0.2887 & 0.3316 \\
\hline 64 & Surgical Instruments & 0.4064 & 0.4519 & 0.5278 \\
\hline 65 & Other Large-scale Manufacturing & 0.5094 & 0.5394 & 0.5894 \\
\hline 66 & Other Small-scale Manufacturing & 0.0000 & 0.0000 & 0.0000 \\
\hline 67 & Low-cost Residential Buildings & 0.0000 & 0.0000 & 0.0000 \\
\hline 68 & Luxurious Residential Buildings & 0.0000 & 0.0000 & 0.0000 \\
\hline 69 & Rural Buildings & 0.0000 & 0.0000 & 0.0000 \\
\hline 70 & Factory Buildings & 0.0000 & 0.0000 & 0.0000 \\
\hline 71 & Public Buildings & 0.0000 & 0.0000 & 0.0000 \\
\hline 72 & Roads & 0.0000 & 0.0000 & 0.0000 \\
\hline 73 & Infrastructure & 0.0000 & 0.0000 & 0.0000 \\
\hline 74 & Ownership of Dwellings & 0.0000 & 0.0000 & 0.0000 \\
\hline 75 & Electricity & 0.0000 & 0.0000 & 0.0000 \\
\hline 76 & Gas & 0.0000 & 0.0000 & 0.0000 \\
\hline 77 & Wholesale \& Retail Trade & 0.0000 & 0.0000 & 0.0000 \\
\hline 78 & Road Transport & 0.0000 & 0.0000 & 0.0000 \\
\hline 79 & Rail Transport & 0.0000 & 0.0000 & 0.0000 \\
\hline 80 & Air Transport & 0.0000 & 0.0000 & 0.0000 \\
\hline 81 & Water Transport & 0.0000 & 0.0000 & 0.0000 \\
\hline 32 & Television & 0.0000 & 0.0000 & 0.0000 \\
\hline 33 & Radio & 0.0000 & 0.0000 & 0.0000 \\
\hline 34 & Phone, Telegraph \& Post & 0.0000 & 0.0000 & 0.0000 \\
\hline 35 & Banking \& Insurance & 0.0000 & 0.0000 & 0.0000 \\
\hline 36 & Government & 0.0000 & 0.0000 & 0.0000 \\
\hline 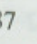 & Services & 0.0000 & 0.0000 & 0.0000 \\
\hline
\end{tabular}


fall in the AR of (9) 'livestock' which is its major input. The same is true for (48) 'petroleum products' due to the reclassification of (12) 'mining and quarrying'. Other changes are relatively insignificant.

Moving from Case A to Case C, when more sectors are treated as non-traded, those manufacturing activities reclassified as non-traded go to zero by definition. There is no effect of any significancs on the social profitability of the agricultural sectors reflecting the fact that manufactures, on the whole, are not important inputs into agricultural activities. However, some manufacturing activities, whose classification between traded and non-traded does not change, exhibit changes in social profitability due to the reclassification of inputs. Table 5 below presents these changes. (These results are for a labour SCF of 0.89 and an asset SCF of 0.75.)

Table 5

Change in Social Profitability for Selected Manufacturing Sectors on Decreasing the Number of Tradeable Sectors (A to C)

\begin{tabular}{lcl}
\hline \multicolumn{1}{c}{ Sector } & $\begin{array}{c}\text { Change in Social } \\
\text { Profitability }\end{array}$ & \multicolumn{1}{c}{$\begin{array}{c}\text { Input Sector } \\
\text { (Sign of AR Change) }\end{array}$} \\
\hline (22) Beverages & +0.106 & (16) Sugar Refining $(-)$ \\
(32) Carpets \& Rugs & -0.060 & (30) Woollen Textiles (+) \\
(44) Paints \& Varnishes & +0.106 & (46) Chemicals (-) \\
(50) Glass \& Products & +0.070 & (46) Chemicals (-) \\
\hline
\end{tabular}

It is also interesting to compare the social profitability presented above with commercial profitability (Table 6) as reflected by the residual. Again we concentrate on Case A for labour SCF of 0.9 and asset SCF of 0.75 . Notice that the residual is calculated as value added less assumed wage and asset costs.

These results suggest that there is a substantial difference between social and commercial profitability and that these differences vary across sectors. However, as we have seen above, the social profitability of some sectors is not sensitive to the SCFs chosen.

For the results presented above we have valued the residual at zero, thus treating it as a transfer with no social cost. The analysis was repeated with the residual valued at 0.8 . This may be interpreted as assuming that profits have a social value of only 0.2 so that a unit of profit received has a social cost of 0.8 . The social profitability of only three sectors exhibits sign changes: (27) 'cotton textiles' from -0.03 to +0.02 ; (36) 'paper and products' from +0.06 to $-0.03 ;(48)$ 'petroleum products' from +0.03 to -0.01 . Social profitability of the sectors does not in general differ with respect to changes in the valuation of the residual.

Table 6

Social Profitability and Commercial Profitability

\begin{tabular}{llcc}
\hline Sector & $\begin{array}{c}\text { Social } \\
\text { Profitability }\end{array}$ & $\begin{array}{c}\text { Commercial } \\
\text { Profitability }\end{array}$ \\
\hline (05) Tobacco Growing & -0.02 & +0.13 \\
(06) Oilseeds & -0.12 & +0.10 \\
(08) Other Crops & -0.33 & +0.10 \\
(15) Edible Oils & +0.07 & -0.04 \\
(22) Beverages & -2.16 & +0.08 \\
(25) Cotton Yarn & -0.05 & +0.07 \\
(30) Woollen Textiles & -0.23 & +0.02 \\
(39) Rubber Footwear & +0.24 & -0.04 \\
(40) Rubber Products & -0.11 & +0.02 \\
(41) Pharmaceuticals & +0.24 & -0.02 \\
(44) Paints and Varnishes & +0.13 & -0.05 \\
(45) Soaps and Detergents & +0.16 & -0.01 \\
(55) Agricultural Machinery & +0.13 & -0.03 \\
(57) Electrical Machinery & +0.09 & -0.01 \\
(59) Transport (LS) & -0.09 & +0.08 \\
(62) Office Equipment & +0.22 & -0.09 \\
\hline
\end{tabular}

\section{POLICY AND FURTHER.RESEARCH}

We have presented calculations of a system of shadow prices which can be used in the appraisal of industrial, commercial and fiscal policy. We have used a reasonably disaggregated inter-industry transaction matrix at purchasers' prices. Alternative sets of shadow prices have been derived for different classifications of activities into traded, non-traded and valuations of factors of production. The broad-ranging set of calculations encompasses several plausible models for commercial policy, labour market and growth possibilities.

Despite the broad range of the sensitivity tests, there are a number of reforms suggested by the analysis that would appear desirable under most of the configurations considered. Thus on the basis of these calculations one might recommend, for instance, that the 'fertilizer' sector be expanded. The social profitabilities indicate the following general directions for industrial and commercial policy. In general, the agricultural sectors are socially profitable, especially sectors (1) 'wheat' and (3) 'cotton'. Given stable world prices, domestic policy should be directed towards increased production in these areas. Although (8) 'other crops' is socially unprofitable throughout, one must be careful in deriving policy conclusions, given the level 
of aggregation of this sector, since individual crops within the classification may be socially profitable. For the most part, manufacturing activities proved socially profitable, especially those classified as exported on the margin, e.g. (64) 'surgical instruments' and (63) 'sports goods'. The textile sectors such as cotton and carpets and rugs also exhibit relatively high social returns. Sectors such as (29) 'silk and synthetic textiles' and (30) 'woollen textiles' are socially unprofitable throughout and 'perfumes and cosmetics' and 'beverages' did not appear to be sectors that should be encouraged greatly.

Notwithstanding the social profitability of 'traditional' sectors, our estimates also point to basic and heavy industry as desirable activities across a wide range of possible valuations of labour and assets. A number of items in Pakistan are subject to high tariff and non-tariff barriers, with the ratio of c.i.f. to domestic prices being as low as 0.12 for (43) "perfumes and cosmetics", or around 0.75 for basic metals and machinery sectors. However, accounting ratios for such sectors are somewhat, though not much, higher, since allowance must be made for trade and transport margins. There is, thus, a supposition that such sectors are heavily protected and are 'inefficient'. However, several sectors are socially profitable and one would point to cement and the basic metals and machinery sectors as examples of non-traditional activities that are socially profitable and that should be encouraged. This is because such sectors use inputs that are also heavily taxed, and which have low accounting ratios. As a result, this leads to overall results in social profitability for some "protected' sectors.

It is important to note that economy-wide shadow prices are at the broad sectoral level but can feed into more detailed analyses of industries within a given sector or at the project level. Other extensions should include an examination of potential changes and the stability of the shadow prices, since policies and international context are both subject to many vagaries. We will use the shadow prices along with the welfare consequences of policy changes in the analysis of the reform along the lines of Ahmad and Stern (1986).

Appendix Table 1(i)

Accounting Ratios for Exportables

\begin{tabular}{lccc}
\hline Commodity & $\begin{array}{c}\text { Value of Exports } \\
\text { (Rs Million) }\end{array}$ & $\begin{array}{c}\text { Export Tax } \\
\text { (Rs Million) }\end{array}$ & $\begin{array}{c}\text { Accounting } \\
\text { Ratio }\end{array}$ \\
\hline Rice & 2479.1 & 241.2 & 1.1078 \\
Cotton (Raw) & 980.5 & 330.0 & 1.5073 \\
Leather & 595.5 & 80.0 & 1.1551 \\
Cotton Waste & 1422.3 & 10.0 & 1.0071 \\
\hline
\end{tabular}

Source: FBS (1983).

Notes: 1. The ARs for all other exportables is one.

2. The exportables are those tradeables which are not importables - see Table 2 and Appendix Table 1(ii) and (iii). 
ARs for Importables Case C

\begin{tabular}{|c|c|c|c|c|c|c|}
\hline & & \multirow{2}{*}{ Commodity } & \multirow{2}{*}{$p_{i}^{c i f}$} & \multicolumn{3}{|c|}{ Labour } \\
\hline & & & & 0.9 & 0.75 & 0.50 \\
\hline 1 & 01 & Wheat & 1.3034 & 1.3821 & 1.3738 & 1.3599 \\
\hline 2 & 05 & Tobacco Growing & 0.6573 & 0.7365 & 0.7268 & 0.7106 \\
\hline 3 & 06 & Oilseeds & 0.6456 & 0.7155 & 0.7065 & 0.6914 \\
\hline 4 & 08 & Other Crops & 0.4966 & 0.5757 & 0.5660 & 0.5498 \\
\hline 5 & 09 & Livestock & 0.9435 & 0.9818 & 0.9778 & 0.9709 \\
\hline 6 & 12 & Mining \& Quarrying & 0.8713 & 0.9408 & 0.9327 & 0.9192 \\
\hline 7 & 15 & Edible Oils & 0.8859 & 0.9562 & 0.9471 & 0.9320 \\
\hline 8 & 16 & Sugar Refining & 0.5716 & 0.6445 & 0.6350 & 0.6191 \\
\hline 9 & 18 & Tea Blending & 0.9185 & 0.9494 & 0.9454 & 0.9388 \\
\hline 10 & 22 & Beverages & 0.0203 & 0.1699 & 0.1521 & 0.1225 \\
\hline 11 & 29 & Silk \& Synthetic Textiles & 0.4147 & 0.5147 & 0.5018 & 0.4804 \\
\hline 12 & 30 & Woollen Textiles \& Hosiery & 0.4405 & 0.5625 & 0.5468 & 0.5207 \\
\hline 13 & 31 & Other Textiles & 0.5339 & 0.6379 & 0.6245 & 0.6023 \\
\hline 14 & 35 & Wood, Cork \& Furniture & 0.9845 & 0.9865 & 0.9863 & 0.9862 \\
\hline 15 & 36 & Paper \& Products & 0.5725 & 0.6935 & 0.6773 & 0.6504 \\
\hline 16 & 40 & Rubber Products & 0.5463 & 0.6743 & 0.6582 & 0.6313 \\
\hline 17 & 41 & Pharmaceutical & 0.8686 & 0.9517 & 0.9414 & 0.9242 \\
\hline 18 & 42 & Fertilizer & 0.7656 & 0.9451 & 0.9305 & 0.9063 \\
\hline 19 & 43 & Perfumes \& Cosmetics & 0.1168 & 0.1802 & 0.1723 & 0.1592 \\
\hline 20 & 44 & Paints \& Varnishes & 0.6942 & 0.7770 & 0.7667 & 0.7495 \\
\hline 21 & 45 & Soaps \& Detergents & 0.8749 & 0.9577 & 0.9474 & 0.9302 \\
\hline 22 & 46 & Chemicals & 0.7485 & .0 .8308 & 0.8206 & 0.8036 \\
\hline 23 & 47 & Plastic Products & 0.8498 & 0.9218 & 0.9136 & 0.8998 \\
\hline 24 & 48 & Petroleum Products & 0.8028 & 0.9021 & 0.8909 & 0.8722 \\
\hline 25 & 50 & Glass \& Products & 0.3091 & 0.3804 & 0.3722 & 0.3585 \\
\hline 26 & 51 & Non-metal Mineral Products & 0.8647 & 0.9654 & 0.9589 & 0.9479 \\
\hline 27 & 52 & Basic Metals & 0.6079 & 0.7623 & 0.7470 & 0.7216 \\
\hline 28 & 53 & Metal Products & 0.7636 & 0.8824 & 0.8694 & 0.8479 \\
\hline 29 & 55 & Agricultural Machinery & 0.8867 & 0.9708 & 0.9648 & 0.9548 \\
\hline 30 & 56 & Other Non-electric Machinery & 0.7716 & 0.8495 & 0.8441 & 0.8352 \\
\hline 31 & 57 & Electric Machinery & 0.7491 & 0.8231 & 0.8180 & 0.8095 \\
\hline 32 & 59 & Transport (Large-scale) & 0.5926 & 0.6774 & 0.6716 & 0.6619 \\
\hline \multirow[t]{2}{*}{33} & 61 & Transport Equipments & & & & \\
\hline & & (Small-scale) & 0.9631 & 0.9876 & 0.9847 & 0.9799 \\
\hline 34 & 62 & Office Equipments & 0.8945 & 0.9659 & 0.9576 & 0.9440 \\
\hline
\end{tabular}

\begin{tabular}{|c|c|c|c|c|c|}
\hline & & \multirow{2}{*}{ Commodity } & \multicolumn{3}{|c|}{ Labour } \\
\hline & & & 0.9 & 0.75 & 0.5 \\
\hline 1 & 01 & Wheat & 1.3820 & 1.3734 & 1.3589 \\
\hline 2 & 05 & Tobacco Growing & 0.7364 & 0.7265 & 0.7100 \\
\hline 3 & 06 & Oilseeds & 0.7155 & 0.7064 & 0.6911 \\
\hline 4 & 08 & Other Crops & 0.5757 & 0.5658 & 0.5493 \\
\hline 5 & 09 & Livestock & 0.9818 & 0.9775 & 0.9705 \\
\hline 6 & 12 & Mining \& Quarrying & 0.9407 & 0.9325 & 0.9188 \\
\hline 7 & 15 & Edible Oils & 0.9561 & 0.9469 & 0.9316 \\
\hline 8 & 22 & Beverages & 0.1697 & 0.1516 & 0.1214 \\
\hline 9 & 31 & Other Textiles & 0.6378 & 0.6243 & 0.6018 \\
\hline 10 & 42 & Fertilizer & 0.9447 & 0.9292 & 0.9034 \\
\hline 11 & 44 & Paints \& Varnishes & 0.7769 & 0.7665 & 0.7491 \\
\hline 12 & 45 & Soaps \& Detergents & 0.9576 & 0.9472 & 0.9298 \\
\hline 13 & 47 & Plastic Products & 0.9217 & 0.9133 & 0.8991 \\
\hline 14 & 50 & Glass \& Products & 0.3803 & 0.3719 & 0.3579 \\
\hline 15 & 51 & Non-metal Mineral Products & 0.9652 & 0.9577 & 0.9452 \\
\hline 16 & 52 & Basic Metals & 0.7621 & 0.7461 & 0.7193 \\
\hline 17 & 53 & Metal Products & 0.8822 & 0.8689 & 0.8466 \\
\hline 18 & 55 & Agricultural Machinery & 0.9706 & 0.9640 & 0.9528 \\
\hline 19 & 56 & Other Non-electric Machinery & 0.8493 & 0.8433 & 0.8332 \\
\hline 20 & 57 & Electric Machinery & 0.8229 & 0.8173 & 0.8080 \\
\hline
\end{tabular}


Appendix Table 2

Value of Imports and c.i.f. Values

\begin{tabular}{|c|c|c|c|c|c|}
\hline & \multicolumn{2}{|c|}{ Commodity } & \multirow{2}{*}{$\begin{array}{c}\begin{array}{c}\text { c.j.f. } \\
\text { Values }\end{array} \\
2992595.1\end{array}$} & \multirow{2}{*}{$\begin{array}{c}\begin{array}{c}\text { Value at } \\
\text { Purchaser } \\
\text { Price }\end{array} \\
2296062.0\end{array}$} & \multirow{2}{*}{$\frac{p_{i}^{\text {cif }}}{1.3034}$} \\
\hline 1 & 01 & Wheat & & & \\
\hline 2 & 02 & Rice & 37.2 & 49.0 & 0.7584 \\
\hline 3 & 03 & Cotton & 0.0 & 0.0 & 0.8177 \\
\hline 4 & 04 & Sugar-cane & 0.0 & 0.0 & 0.8174 \\
\hline 5 & 05 & Tobacco Growing & 17468.4 & 26574.0 & 0.6573 \\
\hline 6 & 06 & Oilseeds & 50504.7 & 78225.0 & 0.6456 \\
\hline 7 & 07 & Pulses & 0.0 & 0.0 & 0.8824 \\
\hline 8 & 08 & Other Crops & 271515.1 & 546751.0 & 0.4966 \\
\hline 9 & 09 & Livestock & 4834.7 & 5124.0 & 0.9435 \\
\hline 10 & 10 & Fishing & 0.0 & 0.0 & 0.8726 \\
\hline 11 & 11 & Forestry & 93190.4 & 115446.0 & 0.8072 \\
\hline 12 & 12 & Mining \& Quarrying & 3461943.7 & 3973445.0 & 0.8713 \\
\hline 13 & 13 & Grain Milling & 0.0 & 0.0 & 0.9503 \\
\hline 14 & 14 & Rice Milling \& Husking & 0.0 & 0.0 & 0.8058 \\
\hline 15 & 15 & Edible Oils & 1825805.5 & 2061018.0 & 0.8859 \\
\hline 16 & 16 & Sugar Refining & 3437.8 & 6014.0 & 0.5716 \\
\hline 17 & 17 & Gur and Khandsari & 0.0 & 0.0 & 0.8862 \\
\hline 18 & 18 & Tea Blending & 1583598.4 & 1724178.0 & 0.9185 \\
\hline 19 & 19 & Fish \& Preparations & 1276.9 & 1495.0 & 0.8541 \\
\hline 20 & 20 & Confectionery \& Bakery & 136.7 & 176.0 & 0.7767 \\
\hline 21 & 21 & Other Food Industries & 594552.6 & 797763.0 & 0.7453 \\
\hline 22 & 22 & Beverages & 251.5 & 12416.0 & 0.0203 \\
\hline 23 & 23 & Cigs. \& Tobacco Products & 16817.6 & 19060.0 & 0.8824 \\
\hline 24 & 24 & Bidis (i.e. Tobacco-SS) & 0.0 & 0.0 & 0.8816 \\
\hline 25 & 25 & Cotton Yarn & 40636.9 & 65113.0 & 0.6241 \\
\hline 26 & 26 & Cotton Ginning & 45977.3 & 79329.0 & 0.5796 \\
\hline 27 & 27 & Cotton Textiles (Large-scale) & 187028.0 & 301963.0 & 0.6194 \\
\hline 28 & 28 & Cotton Textiles (Small-scale) & 0.0 & 0.0 & 0.8776 \\
\hline 29 & 29 & Silk \& Synthetic Textiles & 53605.5 & 129254.0 & 0.4147 \\
\hline 30 & 30 & Woollen Textiles \& Hosiery & 50225.0 & 114019.0 & 0.4405 \\
\hline 31 & 31 & Threadballs \& Other Textiles & 934925.4 & 1751184.0 & 0.5339 \\
\hline 32 & 32 & Carpets \& Rugs & 12806.3 & 14593.0 & 0.8776 \\
\hline 33 & 33 & Made-up Garments & 5877.0 & 6018.0 & 0.9766 \\
\hline 34 & 34 & Footwear (non-rubber) & 584.6 & 620.0 & 0.9430 \\
\hline 35 & 35 & Wood, Cork \& Furniture & 181627.0 & 184483.0 & 0.9845 \\
\hline 36 & 36 & Paper \& Products & 281851.7 & 492313.0 & 0.5725 \\
\hline 37 & 37 & Printing \& Publishing & 23073.7 & 33270.0 & 0.6935 \\
\hline 38 & 38 & Leather \& Products & 87441.8 & 91476.0 & 0.9559 \\
\hline 39 & 39 & Rubber Footwear & 4.0 & 5.0 & 0.8051 \\
\hline 40 & 40 & Rubber Products & 256594.5 & 469707.0 & 0.5463 \\
\hline 41 & 41 & Pharmaceutical & 383390.9 & 441392.0 & 0.8686 \\
\hline 42 & 42 & Fertilizer & 681405.3 & 890057.0 & 0.7656 \\
\hline 43 & 43 & Perfumes \& Cosmetics & 3758.2 & 32167.0 & 0.1168 \\
\hline
\end{tabular}

Appendix Table 2-(Continued)

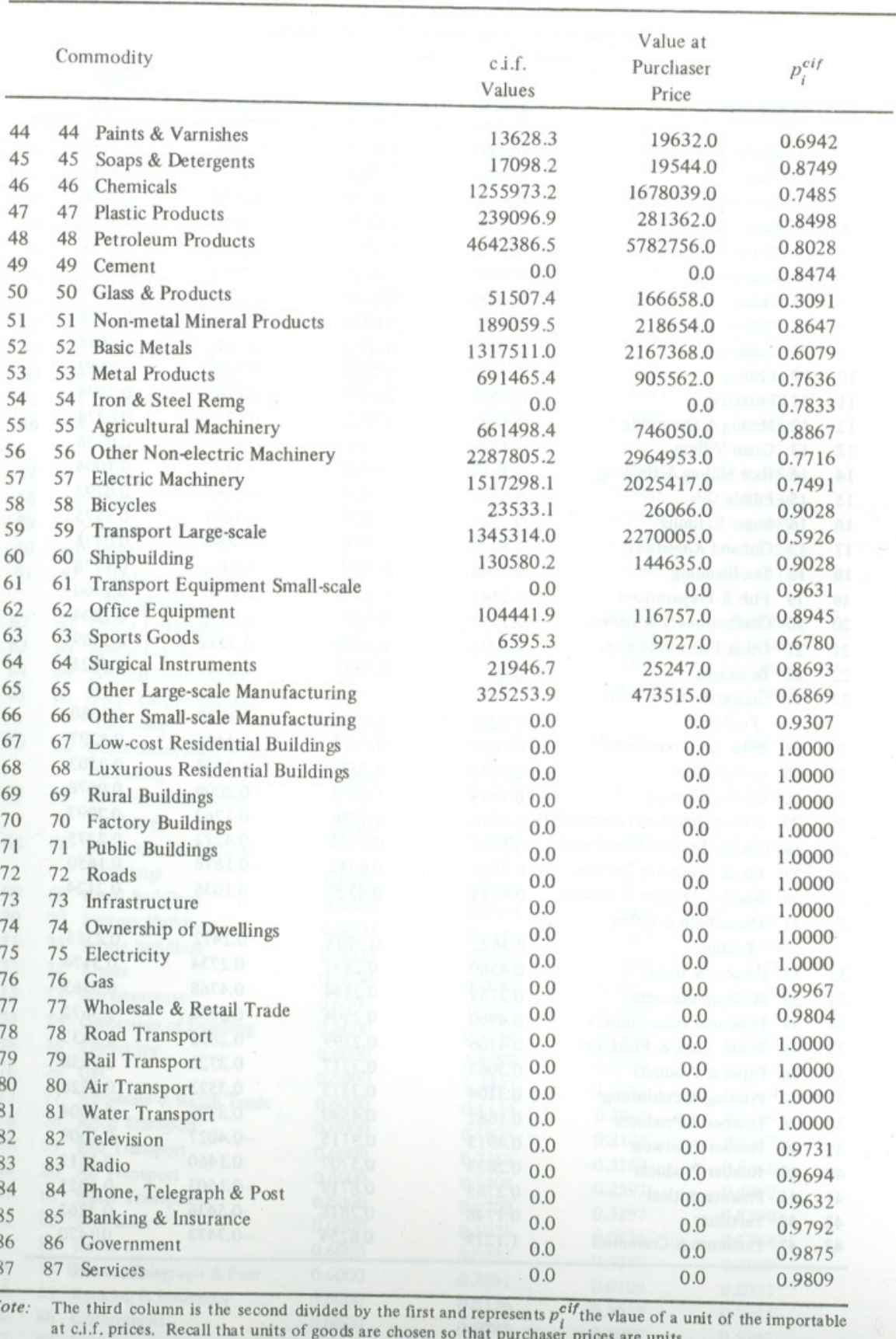


Appendix Table 3

Breakdown of Value Added (\% of Value Added)

\begin{tabular}{|c|c|c|c|c|c|c|}
\hline \multicolumn{3}{|c|}{ Commodity } & \multirow{2}{*}{$\begin{array}{c}\text { Labour } \\
0.5000\end{array}$} & \multirow{2}{*}{$\begin{array}{c}\text { Capital } \\
0.0358\end{array}$} & \multirow{2}{*}{$\begin{array}{c}\text { Residual } \\
0.1642\end{array}$} & \multirow{2}{*}{$\begin{array}{l}\begin{array}{l}\text { Value } \\
\text { Added }\end{array} \\
0.5625\end{array}$} \\
\hline 1 & 01 & Wheat & & & & \\
\hline 2 & 02 & Rice & 0.5000 & 0.0428 & 0.1572 & 0.4712 \\
\hline 3 & 03 & Cotton & 0.5000 & 0.0350 & 0.1650 & 0.5758 \\
\hline 4 & 04 & Sugar-cane & 0.5000 & 0.0305 & 0.1695 & 0.6616 \\
\hline 5 & 05 & Tobacco Growing & 0.5000 & 0.0273 & 0.1727 & 0.7391 \\
\hline 6 & 06 & Oilseeds & 0.5000 & 0.0335 & 0.1665 & 0.6012 \\
\hline 7 & 07 & Pulses & 0.5000 & 0.0855 & 0.1145 & 0.2357 \\
\hline 8 & 08 & Other Crops & 0.5000 & 0.0324 & 0.1676 & 0.6228 \\
\hline 9 & 09 & Livestock & 0.5000 & 0.0355 & 0.1645 & 0.5684 \\
\hline 10 & 10 & Fishing & 0.5000 & 0.0234 & 0.1766 & 0.8609 \\
\hline 11 & 11 & Forestry & 0.5000 & 0.0255 & 0.1745 & 0.7904 \\
\hline 12 & 12 & Mining \& Quarrying & 0.5000 & 0.0628 & 0.1372 & 0.6378 \\
\hline 13 & 13 & Grain Milling & 0.4428 & 1.2166 & -0.6594 & 0.0756 \\
\hline 14 & 14 & Rice Milling \& Husking & 0.4959 & 0.9162 & -0.4121 & 0.1004 \\
\hline 15 & 15 & Edible Oils & 0.3458 & 1.1611 & -0.5068 & 0.0792 \\
\hline 16 & 16 & Sugar Refinining & 0.2541 & 0.5838 & 0.1621 & 0.1575 \\
\hline 17 & 17 & Gur and Khandsari & 0.5000 & 0.1902 & 0.3098 & 0.0871 \\
\hline 18 & 18 & Tea Blending & 0.3248 & 0.5291 & 0.1461 & 0.1738 \\
\hline 19 & 19 & Fish \& Preparations & 0.2547 & 0.6296 & 0.1157 & 0.1460 \\
\hline 20 & 20 & Confectionery \& Bakery & 0.2972 & 0.5097 & 0.1930 & 0.1804 \\
\hline 21 & 21 & Other Food Industries & 0.4090 & 0.2659 & 0.3252 & 0.3459 \\
\hline 22 & 22 & Beverages & 0.4851 & 0.2685 & 0.2464 & 0.3425 \\
\hline \multirow[t]{2}{*}{23} & 23 & Cigarettes \& Tobacco & & & & \\
\hline & & Products & 0.2012 & 0.6661 & 0.1327 & 0.1380 \\
\hline 24 & 24 & Bidis (i.e. Tobacco-SS) & 0.5000 & 0.0502 & 0.4498 & 0.3297 \\
\hline 25 & 25 & Cotton Yarn & 0.3673 & 0.3674 & 0.2653 & 0.2503 \\
\hline 26 & 26 & Cotton Ginning & 0.1514 & 1.0495 & -0.2009 & 0.0876 \\
\hline 27 & 27 & Cotton Textiles (Large-scale) & 0.7376 & 0.4386 & -0.1762 & 0.2097 \\
\hline 28 & 28 & Cotton Textiles (Small-scale) & 0.5000 & 0.0728 & 0.4272 & 0.2275 \\
\hline 29 & 29 & Silk \& Synthetic Textiles & 0.5535 & 0.6343 & -0.1878 & 0.1450 \\
\hline 30 & 30 & Woollen Textiles \& Hosiery & 0.4635 & 0.4329 & 0.1036 & 0.2124 \\
\hline \multirow[t]{2}{*}{31} & 31 & Threadballs \& Other & & & & \\
\hline & & Textiles & 0.3622 & 0.3905 & 0.2472 & 0.2355 \\
\hline 32 & 32 & Carpets \& Rugs & 0.4369 & 0.2897 & 0.2734 & 0.3174 \\
\hline 33 & 33 & Made-up Garments & 0.2789 & 0.2444 & 0.4768 & 0.3763 \\
\hline 34 & 34 & Footwear (non-rubber) & 0.4960 & 0.2504 & 0.2536 & 0.3672 \\
\hline 35 & 35 & Wood, Cork \& Furniture & 0.4706 & 0.2399 & 0.2895 & 0.3833 \\
\hline 36 & 36 & Paper \& Products & 0.3063 & 0.3217 & 0.3720 & 0.2858 \\
\hline 37 & 37 & Printing \& Publishing & 0.3104 & 0.3373 & 0.3523 & 0.2726 \\
\hline 38 & 38 & Leather \& Products & 0.1682 & 0.4590 & 0.3729 & 0.2004 \\
\hline 39 & 39 & Rubber Footwear & 0.4913 & 0.9115 & -0.4027 & 0.1009 \\
\hline 40 & 40 & Rubber Products & 0.2833 & 0.5707 & 0.1460 & 0.1611 \\
\hline 41 & 41 & Pharmaceutical & 0.2785 & 0.8719 & -0.1503 & 0.1055 \\
\hline 42 & 42 & Fertilizer & 0.1746 & 0.2818 & 0.5436 & 0.3263 \\
\hline 43 & 43 & Perfumes \& Cosmetics & 1.1219 & 0.6254 & -0.7473 & 0.1470 \\
\hline
\end{tabular}

Appendix Table 3 - (Continued)

\begin{tabular}{|c|c|c|c|c|c|c|}
\hline \multicolumn{3}{|c|}{ Commodity } & \multirow{2}{*}{$\begin{array}{l}\text { Labour } \\
0.1111\end{array}$} & \multirow{2}{*}{$\begin{array}{l}\text { Capital } \\
2.2353\end{array}$} & \multirow{2}{*}{$\begin{array}{c}\text { Residual } \\
-1.3464\end{array}$} & \multirow{2}{*}{$\begin{array}{l}\begin{array}{l}\text { Value } \\
\text { Added }\end{array} \\
0.0411\end{array}$} \\
\hline 44 & 44 & Paints \& Varnishes & & & & \\
\hline 45 & 45 & Soaps \& Detergents & 0.3283 & 0.7046 & -0.0329 & 0.1305 \\
\hline 46 & 46 & Chemicals & 0.3218 & 0.2898 & 0.3884 & 0.3173 \\
\hline 47 & 47 & Plastic Products & 0.4445 & 0.2399 & 0.3156 & 0.3834 \\
\hline 48 & 48 & Petroleum Products & 0.1743 & 0.6105 & 0.2152 & 0.1506 \\
\hline 49 & 49 & Cement & 0.4311 & 0.4403 & 0.1286 & 0.2089 \\
\hline 50 & 50 & Glass \& Products & 1.7755 & 0.7902 & -1.5657 & 0.1164 \\
\hline 51 & 51 & Non-metal Mineral Products & 0.5023 & 0.3403 & 0.1574 & 0.2702 \\
\hline 52 & 52 & Basic Metals & 0.3557 & 0.5126 & 0.1316 & 0.1794 \\
\hline 53 & 53 & Metal Products & 0.6196 & 0.2177 & 0.1627 & 0.4224 \\
\hline 54 & 54 & Iron \& Steel Remg & 0.5000 & 0.0347 & 0.4653 & 0.4772 \\
\hline 55 & 55 & Agricultural Machinery & 0.4263 & 0.9338 & -0.3601 & 0.0985 \\
\hline \multirow[t]{2}{*}{56} & 56 & Other Non-electric & & & & \\
\hline & & Machinery & 0.2393 & 0.2637 & 0.4970 & 0.3488 \\
\hline 57 & 57 & Electric Machinery & 0.4483 & 0.5949 & -0.0432 & 0.1546 \\
\hline 58 & 58 & Bicycles & 0.2897 & 0.4623 & 0.2479 & 0.1989 \\
\hline 59 & 59 & Transport (Large-scale) & 0.2627 & 0.3957 & 0.3417 & 0.2324 \\
\hline 60 & 60 & Shipbuilding & 0.3321 & 0.2010 & 0.4669 & 0.4575 \\
\hline 61 & 61 & $\begin{array}{l}\text { Transport Equipment (SS) } \\
\text { (Small-scale) }\end{array}$ & 0.5000 & 0.2343 & 0.2657 & 0.3925 \\
\hline 62 & 62 & Office Equipment & 1.0701 & 1.8286 & -1.8987 & 0.0503 \\
\hline 63 & 63 & Sports Goods & 0.2196 & 0.2442 & 0.5362 & 0.3766 \\
\hline 64 & 64 & Surgical Instruments & 0.3305 & 0.1742 & 0.4953 & 0.5278 \\
\hline 65 & 65 & $\begin{array}{l}\text { Other Large-scale Manu- } \\
\text { facturing }\end{array}$ & 0.1679 & 0.1634 & 0.6687 & 0.5629 \\
\hline 66 & 66 & $\begin{array}{l}\text { Other Small-scale Manu- } \\
\text { facturing }\end{array}$ & 0.5000 & 0.0479 & 0.4521 & 0.3459 \\
\hline 67 & 67 & Low-cost Residential & & & & \\
\hline \multirow{3}{*}{68} & & Buildings & 0.6000 & 0.0108 & 0.3892 & 0.4366 \\
\hline & 68 & Luxurious Residential & & & & \\
\hline & & Buildings & 0.6000 & 0.0118 & 0.3882 & 0.3997 \\
\hline 69 & 69 & Rural Buildings & 0.6000 & 0.0094 & 0.3906 & 0.5000 \\
\hline 70 & 70 & Factory Buildings & 0.6000 & 0.0116 & 0.3884 & 0.4036 \\
\hline 71 & 71 & Public Buildings & 0.6000 & 0.0110 & 0.3890 & 0.4258 \\
\hline 72 & 72 & Roads & 0.6000 & 0.0085 & 0.3915 & 0.5549 \\
\hline 73 & 73 & Infrastructure & 0.6000 & 1.2007 & -0.8007 & 0.4165 \\
\hline 74 & 74 & Ownership of Dwelling & 0.6000 & 0.2556 & 0.1444 & 0.8997 \\
\hline 75 & 75 & Electricity & 0.6000 & 1.8999 & -1.4999 & 0.7671 \\
\hline 76 & 76 & Gas & 0.6000 & 1.7862 & -1.3862 & 0.8159 \\
\hline 77 & 77 & Wholesale \& Retail Trade & 0.6000 & 0.1134 & 0.2866 & 0.9449 \\
\hline 78 & 78 & Road Transport & 0.6000 & 0.1825 & 0.2175 & 0.3157 \\
\hline 79 & 79 & Rail Transport & 0.6000 & 0.7169 & -0.3169 & 0.5510 \\
\hline 80 & 80 & Air Transport & 0.6000 & 0.1408 & 0.2592 & 0.4092 \\
\hline 81 & 81 & Water Transport & 0.6000 & 0.0703 & 0.3297 & 0.8198 \\
\hline 82 & 82 & Television & 0.6000 & 0.1076 & 0.2924 & 0.5354 \\
\hline 83 & 83 & Radio & 0.6000 & 0.0751 & 0.3249 & 0.7669 \\
\hline 84 & 84 & Phone, Telegraph \& Post & 0.6000 & 0.3891 & 0.0109 & 0.8055 \\
\hline 85 & 85 & Banking \& Insurance & 0.6000 & 0.0376 & 0.3624 & 0.7285 \\
\hline 86 & 86 & Government & 0.6000 & 0.5082 & -0.1082 & 0.5342 \\
\hline 87 & 87 & Services & 0.6000 & 0.1119 & 0.2881 & 0.9581 \\
\hline
\end{tabular}




\begin{tabular}{|c|c|c|c|c|c|}
\hline & & \multirow{2}{*}{ Commodity } & \multicolumn{3}{|c|}{ Labour } \\
\hline & & & 0.9 & 0.75 & 0.5 \\
\hline 1 & 04 & Sugar-cane & 0.7532 & 0.6833 & 0.5669 \\
\hline 2 & 07 & Pulses & 0.8870 & 0.8511 & 0.7913 \\
\hline 3 & 11 & Forestry & 0.7239 & 0.6479 & 0.5211 \\
\hline 4 & 13 & Grain Milling & 1.3168 & 1.3003 & 1.2728 \\
\hline 5 & 14 & Rice Milling \& Husking & 1.0503 & 1.0310 & 0.9989 \\
\hline 6 & 17 & Gur and Khandsari & 0.7272 & 0.6549 & 0.5344 \\
\hline 7 & 20 & Confectionery \& Bakery & 0.7554 & 0.7221 & 0.6666 \\
\hline 8 & 24 & Bidis (i.e. Tobacco-SS) & 0.6028 & 0.5456 & 0.4504 \\
\hline 9 & 26 & Cotton Ginning & 1.3572 & 1.3478 & 1.3322 \\
\hline 10 & 37 & Printing \& Publishing & 0.6540 & 0.6114 & 0.5404 \\
\hline 11 & 54 & Iron \& Steel Remg & 0.5907 & 0.5189 & 0.3992 \\
\hline 12 & 58 & Bicycles & 0.7707 & 0.7474 & 0.7086 \\
\hline 13 & 60 & Shipbuilding & 0.8575 & 0.8179 & 0.7520 \\
\hline 14 & 66 & Other Small-scale Manufacturing & 0.6075 & 0.5664 & 0.4979 \\
\hline 15 & 67 & Low-cost Residential Buildings & 0.7586 & 0.7114 & 0.6327 \\
\hline 16 & 68 & Luxurious Residential Buildings & 0.7361 & 0.6869 & 0.6050 \\
\hline 17 & 69 & Rural Buildings & 0.7175 & 0.6585 & 0.5601 \\
\hline 18 & .70 & Factory Buildings & 0.7349 & 0.6883 & 0.6106 \\
\hline 19 & 71 & Public Buildings & 0.7219 & 0.6695 & 0.5824 \\
\hline 20 & 72 & Roads & 0.7321 & 0.6793 & 0.5913 \\
\hline 21 & 73 & Infrastructure & 1.1055 & 1.0556 & 0.9725 \\
\hline 22 & 74 & Ownership of Dwellings & 0.7329 & 0.6476 & 0.5054 \\
\hline 23 & 75 & Electricity & 1.7579 & 1.6825 & 1.5568 \\
\hline 24 & 76 & Gas & 1.7071 & 1.6311 & 1.5044 \\
\hline 25 & 77 & Wholesale \& Retail Trade & 0.6330 & 0.5441 & 0.3960 \\
\hline 26 & 78 & Road Transport & 0.7499 & 0.7046 & 0.6290 \\
\hline 27 & 79 & Rail Transport & 0.9674 & 0.9114 & 0.8183 \\
\hline 28 & 80 & Air Transport & 0.7170 & 0.6567 & 0.5563 \\
\hline 29 & 81 & Water Transport & 0.6352 & 0.5527 & 0.4151 \\
\hline 30 & 82 & Television & 0.7527 & 0.6955 & 0.6003 \\
\hline 31 & 83 & Radio & 0.6769 & 0.5954 & 0.4595 \\
\hline 32 & 84 & Phone, Telegraph \& Post & 0.8203 & 0.7375 & 0.5996 \\
\hline 33 & 85 & Banking \& Insurance & 0.6528 & 0.5719 & 0.4369 \\
\hline 34 & 86 & Government & 0.8379 & 0.7582 & 0.6253 \\
\hline 35 & 87 & Services & 0.6330 & 0.5444 & 0.3967 \\
\hline
\end{tabular}

\begin{tabular}{|c|c|c|c|c|c|}
\hline & & \multirow{2}{*}{ Commodity } & \multicolumn{3}{|c|}{ Labour } \\
\hline & & & 0.9 & 0.75 & 0.5 \\
\hline 1 & 04 & Sugar-cane & 0.7386 & 0.6687 & 0.5523 \\
\hline 2 & 07 & Pulses & 0.8705 & 0.8346 & 0.7749 \\
\hline 3 & 11 & Forestry & 0.7127 & 0.6366 & 0.5099 \\
\hline 4 & 13 & Grain Milling & 1.2846 & 1.2681 & 1.2406 \\
\hline 5 & 14 & Rice Milling \& Husking & 1.0141 & 0.9949 & 0.9627 \\
\hline 6 & 17 & Gur and Kharidsari & 0.7075 & 0.6351 & 0.5146 \\
\hline 7 & 20 & Confectionery \& Bakery & 0.7160 & 0.6827 & 0.6273 \\
\hline 8 & 24 & Bidis (i.e. Tobacco-SS) & 0.5889 & 0.5317 & 0.4364 \\
\hline 9 & 26 & Cotton Ginning & 1.3301 & 1.3208 & 1.3052 \\
\hline 10 & 37 & Printing \& Publishing & 0.6178 & 0.5752 & 0.5041 \\
\hline 11 & 54 & Iron \& Steel Remg & 0.5674 & 0.4956 & 0.3760 \\
\hline 12 & 58 & Bicycles & 0.7381 & 0.7148 & 0.6760 \\
\hline 13 & 60 & Shipbuilding & 0.8196 & 0.7800 & 0.7141 \\
\hline 14 & 66 & Other Small-scale Manufacturing & 0.5972 & 0.5561 & 0.4876 \\
\hline 15 & 67 & Low-cost Residential Buildings & 0.7545 & 0.7073 & 0.6286 \\
\hline 16 & 68 & Luxurious Residential Buildings & 0.7293 & 0.6801 & 0.5981 \\
\hline 17 & 69 & Rural Buildings & 0.7115 & 0.6524 & 0.5540 \\
\hline 18 & 70 & Factory Buildings & 0.7301 & 0.6835 & 0.6058 \\
\hline 19 & 71 & Public Buildings & 0.7147 & 0.6624 & 0.5752 \\
\hline 20 & 72 & Roads & 0.7295 & 0.6767 & 0.5888 \\
\hline 21 & 73 & Infrastructure & 0.9722 & 0.9223 & 0.8392 \\
\hline 22 & 74 & Ownership of Dwellings & 0.6749 & 0.5896 & 0.4473 \\
\hline 23 & 75 & Electricity & 1.3735 & 1.2981 & 1.1724 \\
\hline 24 & 76 & Gas & 1.3399 & 1.2639 & 1.1372 \\
\hline 25 & 77 & Wholesale \& Retail Trade & 0.6032 & 0.5143 & 0.3662 \\
\hline 26 & 78 & Road Transport & 0.7263 & 0.6809 & 0.6053 \\
\hline 27 & 79 & Rail Transport & 0.8659 & 0.8100 & 0.7169 \\
\hline 28 & 80 & Air Transport & 0.6886 & 0.6283 & 0.5279 \\
\hline 29 & 81 & Water Transport & 0.6135 & 0.5309 & 0.3933 \\
\hline 30 & 82 & Television & 0.7287 & 0.6715 & 0.5763 \\
\hline 31 & 83 & Radio & 0.6393 & 0.5578 & 0.4219 \\
\hline 32 & 84 & Phone, Telegraph \& Post & 0.7331 & 0.6503 & 0.5124 \\
\hline 33 & 85 & Banking \& Insurance & 0.6251 & 0.5441 & 0.4092 \\
\hline 34 & 86 & Government & 0.7494 & 0.6696 & 0.5367 \\
\hline 35 & 87 & Services & 0.6033 & 0.5147 & 0.3671 \\
\hline
\end{tabular}


Appendix Table 4(iii)

Case A: Non-traded ARs to Accounting (Asset $S C F=0.25$ )

\begin{tabular}{|c|c|c|c|c|c|}
\hline & & \multirow{2}{*}{ Commodity } & \multicolumn{3}{|c|}{ Labour } \\
\hline & & & 0.9 & 0.75 & 0.5 \\
\hline 1 & 04 & Sugar-cane & 0.7240 & 0.6541 & 0.5377 \\
\hline 2 & 07 & Pulses & 0.8540 & 0.8181 & 0.7584 \\
\hline 3 & 11 & Forestry & 0.7015 & 0.6254 & 0.4987 \\
\hline 4 & 13 & Grain Milling & 1.2523 & 1.2358 & 1.2083 \\
\hline 5 & 14 & Rice Milling \& Husking & 0.9780 & 0.9587 & 0.9266 \\
\hline 6 & 17 & Gur and Khandsari & 0.6877 & 0.6154 & 0.4948 \\
\hline 7 & 20 & Confectionery \& Bakery & 0.6767 & 0.6434 & 0.5879 \\
\hline 8 & 24 & Bidis (i.e. Tobacco-SS) & 0.5749 & 0.5177 & 0.4224 \\
\hline 9 & 26 & Cotton Ginning & 1.3031 & 1.2937 & 1.2782 \\
\hline 10 & 37. & Printing \& Publishing & 0.5815 & 0.5389 & 0.4679 \\
\hline 11 & 54 & Iron \& Steel Remg & 0.5441 & 0.4723 & 0.3527 \\
\hline 12 & 58 & Bicycles & 0.7055 & 0.6822 & 0.6434 \\
\hline 13 & 60 & Shipbuilding & 0.7817 & 0.7422 & 0.6762 \\
\hline 14 & 66 & Other Small-scale Manufacturing & 0.5870 & 0.5459 & 0.4774 \\
\hline 15 & 67 & Low-cost Residential Buildings & 0.7505 & 0.7033 & 0.6246 \\
\hline 16 & 68 & Luxurious Residential Buildings & 0.7224 & 0.6733 & 0.5913 \\
\hline 17 & 69 & Rural Buildings & 0.7055 & 0.6464 & 0.5480 \\
\hline 18 & 70 & Factory Buildings & 0.7254 & 0.6787 & 0.6010 \\
\hline 19 & 71 & Public Buildings & 0.7075 & 0.6552 & 0.5680 \\
\hline 20 & 72 & Roads & 0.7269 & 0.6741 & 0.5862 \\
\hline 21 & 73 & Infrastructure & 0.8389 & 0.7890 & 0.7059 \\
\hline 22 & 74 & Ownership of Dwellings & 0.6169 & 0.5315 & 0.3893 \\
\hline 23 & 75 & Electricity & 0.9892 & 0.9137 & 0.7880 \\
\hline 24 & 76 & Gas & 0.9727 & 0.8967 & 0.7700 \\
\hline 25 & 77 & Wholesale \& Retail Trade & 0.5734 & 0.4845 & 0.3363 \\
\hline 26 & 78 & Road Transport & 0.7026 & 0.6572 & 0.5816 \\
\hline 27 & 79 & Rail Transport & 0.7645 & 0.7086 & 0.6155 \\
\hline 28 & 80 & Air Transport & 0.6602 & 0.5999 & 0.4995 \\
\hline 29 & 81 & Water Transport & 0.5917 & 0.5092 & 0.3716 \\
\hline 30 & 82 & Television & 0.7047 & 0.6475 & 0.5523 \\
\hline 31 & 83 & Radio & 0.6017 & 0.5201 & 0.3842 \\
\hline 32 & 84 & Phone, Telegraph \& Post & 0.6458 & 0.5631 & 0.4252 \\
\hline 33 & 85 & Banking \& Insurance & 0.5973 & 0.5164 & 0.3814 \\
\hline 34 & 86 & Government & 0.6608 & 0.5810 & 0.4481 \\
\hline 35 & 87 & Services & 0.5737 & 0.4851 & 0.3374 \\
\hline
\end{tabular}

\section{REFERENCES}

Ahmad, S. E., and N. H. Stern (1984). "The Theory of Reform and Indian Indirect Taxes". Journal of Public Economics. Vol. 25, No. 3. pp. 259-298.

Ahmad, S. E., and N. H. Stern (1986). "Tax Reform for Pakistan: Overview and Effective Taxes for 1975-76". Pakistan Development Review. Vol. XXV, No. 1. Spring. pp. 43-72.

Ahmad, S. E., and N. H. Stern. Tax Reform and Developmerit. New York: Cambridge University Press. (Forthcoming)

Dasgupta, P., S. Marglin and A. K. Sen (1972). Guidelines for Project Evaluation. New York: UNIDO.

Dervis, D., J. De Melo and S. Robinson (1982). General Equilibrium Models for Development Policy. New York: Cambridge Univesity Press.

Diamond P. A., and J. A. Mirrlees (1976). "Private Constant Returns and Public Shadow Prices”. Review of Economic Studies. pp. 41- 48.

Drèze, J. P., and N. H. Stern (1987). "The Theory of Cost-benefit Analysis". In A. Auerbach and M. Feldstein (eds.), Handbook of Public Economics. Volume II. North-Holland.

Government of Pakistan. Federal Bureau of Statistics (1983). Ten Years of Pakistan Statistics 1972-82. Karachi.

Government of Pakistan. Federal Bureau of Statistics (1982). National Accounts of Pakistan (Product and Expenditure). Karachi.

Government of Pakistan. Ministry of Finance (1976). Explanatory Memorandum on the Budget 1976-77. Islamabad.

Khan, S. R. (1974). "An Estimation of the Shadow Wage Rate in Pakistan". Pakistan Development Review. Vol. XIII. pp. 389-408.

Little, I. M. D., and J. A. Mirrlees (1974). Project Appraisal and Planning for Developing Countries. London: Heinemann.

Naqvi, Syed Nawab Haider, and A. R. Kemal (1983). The Structure of Protection in Pakistan: 1980-81. Islamabad: Pakistan Institute of Development Economics.

Pakistan Institute of Development Economics (1985). "Final P.I.D.E. Input-Output Table of Pakistan's Economy: 1975-76”. Islamabad. (Research Reports Series No. 139)

Squire, L., I. M. D. Little and M. Durdag (1979). "Shadow Pricing and Macroeconomic Analysis: Some Illustrations from Pakistan". Pakistan Development Review. Vol. XVIII, No. 2. pp. 89-112.

Stern, N. H. (1984). "Optimum Taxation and Tax Policy". International Monetary Fund Staff Papers. Vol. 31, No. 2. pp. 339-378. 